\title{
PENGEMBANGAN PERANGKAT PEMBELAJARAN BERBASIS MODEL LEARNING CYCLE $5 E$ UNTUK MENINGKATKAN PENGUASAAN KONSEP DAN KETERAMPILAN BERPIKIR KRITIS SISWA SMK PADA MATERI POKOK LAJU REAKSI
}

\author{
Erie Verawati ${ }^{1)}$ \\ Suyatno $^{2)}$ \\ Wahono $^{3}$ \\ ${ }^{1)}$ Mahasiswa Prodi Pendidikan Sains, Program Pascasarjana, Universitas Negeri Surabaya \\ ${ }^{2)}$ Dosen Program Studi Pendidikan Sains, Program Pascasarjana Universitas Negeri Surabaya \\ ${ }^{3)}$ Dosen Program Studi Pendidikan Sains, Program Pascasarjana Universitas Negeri Surabaya \\ e-mail: erieverawati.kimiasmkn2tarakan@gmail.com
}

\begin{abstract}
Abstrak: Penelitian ini bertujuan untuk mendeskripsikan kelayakan perangkat pembelajaran berbasis model learning cycle $5 E$ untuk meningkatkan penguasaan konsep dan keterampilan berpikir kritis siswa kelas XI semester genap SMKN 2 Tarakan pada materi pokok laju reaksi. Jenis penelitian adalah penelitian pengembangan perangkat pembelajaran. Model pengembangan perangkat yang digunakan adalah model 4D, tetapi hanya sampai tahap pengembangan (develop). Uji coba perangkat pembelajaran di dalam kelas menggunakan rancangan one group pretest-postest design. Hasil penelitian menunjukkan bahwa RPP, Handout, dan LKS berkategori baik. Tes penguasaan konsep dan tes keterampilan berpikir kritis berkategori valid. Keterbacaan handout dan LKS tergolong baik. Keterlaksanaan RPP tergolong baik. Aktivitas siswa yang menonjol adalah membaca (mencari informasi dan sebagainya) (15\%), melakukan percobaan untuk menguji hipotesis secara berkelompok (13\%), dan menyampaikan pendapat atau mengkomunikasikan informasi kepada kelas dan guru dalam diskusi kelas (13\%). Respon siswa terhadap pembelajaran sangat baik. Ketuntasan klasikal penguasaan konsep adalah 91\% dengan skor rata-rata 79,61 dan skor rata-rata peningkatan (gain) 0,8 (kategori tinggi). Rata-rata skor keterampilan berpikir kritis sebesar 82,44 dengan skor peningkatan 0,8 (kategori tinggi). Kendala dalam pembelajaran berbasis learning cycle 5E adalah jumlah siswa yang cukup besar dan pengelolaan kelas kurang efektif sehingga masih ada siswa yang kurang terperhatikan, kurangnya alat-alat praktikum yang dibutuhkan, serta kendala dalam waktu pembelajaran, dengan cukup banyaknya siswa sehingga waktu yang diperlukan menjadi lebih banyak untuk membagi alat, bahan praktikum, handout, LKS, soal tes, serta angket. Berdasarkan temuan hasil penelitian dapat disimpulkan bahwa perangkat pembelajaran berbasis model learning cycle $5 E$ yang dihasilkan telah layak dan dapat digunakan dalam pembelajaran untuk meningkatkan penguasaan konsep dan keterampilan berpikir kritis siswa.
\end{abstract}

Kata Kunci: Model Learning Cycle 5E, Penguasaan Konsep, Keterampilan Berpikir Kritis.

\begin{abstract}
The aim of this research is to describe the feasibility of learning materials based on 5E learning cycle model to improve student concept mastery and critical thinking skills of grade XI even semester SMKN 2 Tarakan on rate of reaction topic. This research is development research using $4 D$ models as instructional design. The test design of the implementation of the teaching materials use one group pretest-posttest design. The result of this research is Lesson Plan (RPP), Handout, and Student Worksheets (LKS) categorized good. Concept Mastery Test and Critical Thinking Skills Test categorized valid. Handouts and student worksheets have high legibility. Implementation of RPP is good. Prominent student activity in learning based on $5 E$ learning cycle model are reading (looking for information, etc.) (15\%), do an experiment to test the hypothesis in groups (13\%), and express opinions or communicate information in discussion (13\%). Students' response to learning were very good. Classical completeness concept mastery is $91 \%$ with an average score 79.61 and improvement average score (gain) is 0.8 (high category). The average score of critical thinking skills is 82.44 and improvement average score (gain) is 0.8 (high category). Obstacles in the learning based $5 E$ learning cycle model are the number of students are many and less effective of classroom management so there are students who are less attention; lack of lab tools; and obstacles in the learning time, because the number of students are many so it take a lot of time to divide lab tools, lab materials, handouts, worksheets, test questions, and questionnaires. Based on the result of the analysis data can be concluded that learning materials based on $5 E$ learning cycle model produced is feasible so it can be used in learning to improve student concept mastery and critical thinking skills.
\end{abstract}

Keywords: 5E Learning Cycle Model, Concept Mastery, Critical Thinking Skills.

\section{PENDAHULUAN}

Pendidikan kimia sebagai bagian dari pendidikan sains berperan penting dalam kehidupan manusia. Pendidikan kimia berkembang seiring perkembangan sains dan teknologi di abad ke-21. Pendidikan abad ke-21 menghendaki dihasilkannya siswa yang mempunyai keterampilan berpikir, salah satunya adalah keterampilan berpikir kritis, agar dapat bertahan menghadapi persaingan pada era globalisasi saat ini (Partnership for 21st Century Skills, 2008).

Sebagaimana menurut Wagner (2008), siswa saat ini perlu menguasai tujuh keterampilan bertahan hidup agar berhasil di dunia kerja baru. Keterampilanketerampilan ini memungkinkan siswa menjadi warga negara yang produktif, sehingga dapat memberikan kontribusi dalam memecahkan beberapa masalah penting di abad ke-21. Tujuh keterampilan bertahan 
hidup tersebut meliputi berpikir kritis dan pemecahan masalah.

Menurut IMLS keterampilan belajar dan keterampilan inovasi abad ke-21 yang harus dikuasai meliputi: berpikir kritis dan pemecahan masalah, kreativitas dan inovasi, komunikasi dan kolaborasi, literasi visual, literasi ilmiah dan numerik, berpikir lintas disiplin, dan literasi dasar (Institute of Museum and Library Services, 2009).

Pemerintah Indonesia melalui Permendiknas No. 23 Tahun 2006 menghendaki lulusan SMK/MAK untuk mampu membangun dan menerapkan informasi dan pengetahuan secara logis, kritis, kreatif, dan inovatif serta dapat menunjukkan kemampuan berpikir logis, kritis, kreatif, dan inovatif dalam pengambilan keputusan secara mandiri (Permendiknas, 2006). Siswa lulusan SMK diharapkan mampu berpikir kritis secara mandiri, karena siswa SMK diharapkan siap memasuki dunia kerja setelah lulus sekolah, sehingga cara berpikirnya akan sangat menentukan keberhasilannya.

Kurikulum 2013, melalui Permendikbud No. 70 Tahun 2013 mengamanatkan siswa kelas X dan XI SMK untuk mampu menunjukkan perilaku ilmiah (salah satunya kritis) dalam aktivitas sehari-hari sebagai wujud implementasi sikap dalam melakukan percobaan dan diskusi (Permendikbud, 2013).

Keterampilan berpikir kritis sangat diperlukan siswa agar menjadi pemecah masalah yang tangguh, pembuat keputusan yang matang, dan orang yang tak pernah berhenti belajar. Penting bagi siswa untuk menjadi seorang pemikir mandiri sejalan dengan meningkatnya jenis pekerjaan di masa mendatang yang membutuhkan para pekerja handal yang memiliki kemampuan berpikir kritis. Salah satu dari fungsi sekolah adalah menyediakan tenaga kerja yang mumpuni dan siap dengan berbagai masalah yang ada, maka penting pembelajaran berpikir dimasukkan ke dalam proses pembelajaran.

Selama ini, kemampuan berpikir kritis masih belum terjiwai oleh siswa sehingga hasil belajar siswa belum maksimal. Hal ini disebabkan kebanyakan guru hanya mengejar ketuntasan materi, kurang memikirkan bagaimana siswa belajar dan mengembangkan kemampuannya, termasuk kemampuan berpikir kritis.

Berdasarkan hasil observasi awal uji berpikir kritis pada materi faktor-faktor yang mempengaruhi laju reaksi di kelas XII TKJ di SMKN 2 Tarakan, dari sepuluh indikator yang diobservasi menghasilkan lima indikator dengan hasil terendah, yaitu: (1) Menjawab pertanyaan mengapa, (2) Kemampuan memberikan alasan, (3) Membuat generalisasi, kesimpulan dan hipotesis, (4) Merumuskan alternatif yang memungkinkan untuk memecahkan masalah, dan (5) Mengaplikasikan prinsip yang diterima. Hal ini menunjukkan keterampilan berpikir siswa, terutama pada lima indikator tersebut masih cukup rendah sehingga masih perlu ditingkatkan. Sementara data nilai ulangan harian pokok bahasan laju reaksi yang diajarkan dengan metode konvensional di SMKN 2 Tarakan, 45\% siswa masih belum tuntas, sehingga penguasaan konsep siswa terhadap materi laju reaksi juga masih perlu perbaikan.

Kondisi pendidikan sains, yang di dalamnya terdapat pendidikan kimia, di Indonesia saat ini masih belum berkembang secara optimal dan masih tergolong rendah. Hal ini berarti peningkatan dan pengembangan mutu pembelajaran sains harus menjadi prioritas dan mutlak dilakukan. Fakta yang dapat dijadikan indikator masih rendahnya mutu pembelajaran sains di Indonesia adalah data hasil studi TIMSS (Trends in International Mathematics and Science Study).

TIMSS yang merupakan studi internasional tentang prestasi matematika dan sains siswa SLTP menguji kemampuan siswa dalam domain kognitif yang terdiri dari pengetahuan, penerapan, dan penalaran. Indonesia untuk bidang sains berdasarkan hasil survey TIMSS 2007 berada pada peringkat 35 dari 46 negara peserta dan pada tahun 2011 peringkat Indonesia semakin menurun (Balitbang Kemendikbud, 2011). Hal ini menunjukkan kemampuan sains siswa Indonesia masih sangat rendah.

Rendahnya kemampuan sains siswa tentunya bukan karena faktor pengetahuan yang bersifat hafalan, melainkan pada faktor penerapan dan penalaran yang masih cukup rendah sehingga perlu usaha yang keras untuk meningkatkannya. Penerapan dan penalaran ini merupakan bagian dari indikator keterampilan berpikir kritis sehingga rendahnya kemampuan penerapan dan penalaran dapat digunakan sebagai indikator rendahnya keterampilan berpikir kritis siswa. Jika siswa pada SLTP memiliki keterampilan berpikir kritis yang rendah tentu saja mengindikasikan bahwa SLTA, terutama kelas $\mathrm{X}$ dan $\mathrm{XI}$, juga cenderung memiliki keterampilan berpikir kritis yang masih rendah.

Di SMK, kimia merupakan salah satu mata pelajaran adaptif yang merupakan penunjang untuk mata pelajaran produktif (kejuruan). Mata pelajaran adaptif menuntut siswa mampu memahami dan menguasai konsep serta prinsip dasar ilmu pengetahuan dan teknologi yang dapat diterapkan dalam kehidupan sehari-hari dan melandasi kompetensi untuk bekerja. Pembelajaran kimia diharapkan tidak sekedar mengajarkan konsep kimia, tetapi mampu memberikan dasar bagi siswa disaat memerlukan konsep-konsep tersebut untuk menyelesaikan permasalahan yang ada pada mata pelajaran produktifnya (Yulianti, 2010).

Salah satu cara untuk membantu siswa menghubungkan antara ilmu pengetahuan yang 
dipelajari di kelas dengan pengalaman pribadi siswa adalah model pembelajaran learning cycle $5 E$. Menurut Llewellyn (2007) sebagaimana dikutip Hokkanen (2011: 5) bahwa model 5E dapat membantu "siswa bergerak dari pengalaman konkret, untuk pengembangan pemahaman, dengan penerapan prinsipprinsip." Model learning cycle $5 E$ direkomendasikan untuk mengajar dalam teori belajar konstruktivis karena model learning cycle $5 E$ dikenal sebagai model yang lebih baik daripada pembelajaran tradisional (Ergin et. al., 2008).

Meskipun model-model konstruktivis seperti $3 E$, $4 E, 5 E$, dan $7 E$ memiliki langkah-langkah yang serupa, $5 E$ adalah versi yang paling popular (Turk \& Calik, 2008). Kegiatan pembelajaran model learning cycle $5 E$ berusaha untuk membangkitkan minat siswa pada pelajaran kimia (engagement), memberikan kesempatan kepada siswa untuk memanfaatkan panca indera mereka semaksimal mungkin dalam berinteraksi dengan lingkungan melalui kegiatan telaah literatur atau percobaan (exploration), memberikan kesempatan yang luas kepada siswa untuk menyampaikan ide atau gagasan yang mereka miliki melalui kegiatan diskusi (explanation), mengajak siswa mengaplikasikan konsep-konsep yang mereka dapatkan dengan mengerjakan soal-soal pemecahan masalah (elaboration) dan menyelesaikan tes akhir untuk mengetahui tingkat pemahaman siswa terhadap konsep yang telah dipelajari (evaluation).

Aydin \& Yilmas (2010) menunjukkan bahwa model pembelajaran learning cycle $5 E$ lebih berpengaruh dalam meningkatkan keterampilan kognitif tingkat tinggi siswa dalam materi asam basa, daripada pembelajaran tradisional, serta mempengaruhi sikap siswa yang menjadi lebih positif terhadap mata pelajaran kimia di sekolah. Soeprodjo (2008) menyimpulkan bahwa ada pengaruh positif penggunaan model learning cycle terhadap hasil belajar siswa kelas XI semester 2 SMA Negeri 1 Temanggung pada pokok bahasan kelarutan dan hasil kali kelarutan.

Upaya perbaikan kualitas pembelajaran dapat diawali dengan perencanaan pembelajaran. Perangkat pembelajaran merupakan salah satu wujud persiapan yang dilakukan oleh guru sebelum mereka melakukan proses pembelajaran (Hudha dkk., 2011). Penelitian terhadap pengembangan perangkat pembelajaran learning cycle $5 E$ untuk meningkatkan penguasaan konsep dan keterampilan berpikir siswa pada materi laju reaksi belum pernah dilakukan sehingga peneliti menganggap perlu untuk mengadakan penelitian yang bertujuan untuk mendeskripsikan kelayakan perangkat pembelajaran berbasis model learning cycle $5 E$ untuk meningkatkan penguasaan konsep dan keterampilan berpikir kritis siswa SMK pada materi pokok laju reaksi yang dikembangkan oleh peneliti.

\section{METODE}

Jenis penelitian ini adalah penelitian pengembangan karena ditujukan untuk mengembangkan perangkat pembelajaran berbasis model learning cycle $5 E$ pada materi laju reaksi. Subyek dalam penelitian ini adalah perangkat pembelajaran berbasis model learning cycle $5 E$ yang diterapkan pada siswa kelas XI SMKN 2 Tarakan. Kelas uji coba dipilih secara pengundian yang akhirnya diterapkan pada kelas XI Teknik Komputer dan Jaringan (TKJ) yang terdiri dari 32 siswa.

Model pengembangan perangkat yang digunakan adalah model 4D (four D model) dari Thiagarajan (1974), yang terdiri dari 4 tahap, yaitu pendefinisian (Define), perancangan (Design), pengembangan (Develop), dan penyebaran (Dessiminate). Namun dalam penelitian ini hanya dibatasi sampai tahap pengembangan.

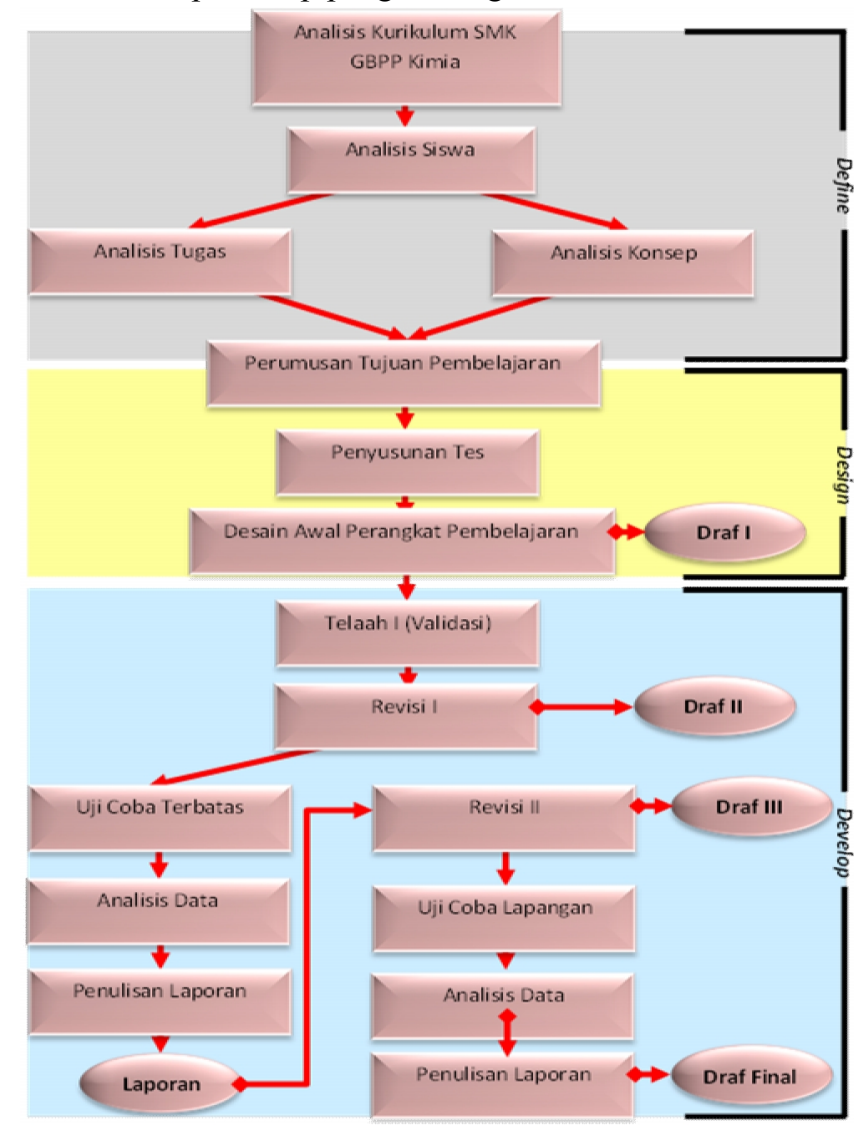

Gambar 1. Model Pengembangan Perangkat Pembelajaran 4D (Diadaptasi dari Ibrahim, 2002).

Kegiatan uji coba dilakukan dengan membandingkan hasil sebelum dan sesudah implementasi model pembelajaran learning cycle $5 E$ hanya pada satu kelas, tanpa kelas kontrol menggunakan rancangan one group pretest-postets design (Fraenkel, 2012) sebagai berikut: 


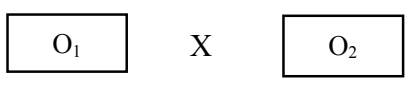

\section{Keterangan:}

$\mathrm{O}_{1}$ : Pengujian awal (pre test) sebelum pemberian perlakuan

O2 : Pengujian akhir (post test) setelah pemberian perlakuan

$\mathrm{X}$ : Perlakuan dengan penerapan model learning cycle $5 E$

\section{Teknik Analisis Data}

\section{Validitas RPP, Handout, dan LKS}

RPP, Handout, dan LKS yang telah divalidasi dianalisis secara deskriptif kualitatif dengan kriteria:

Sangat Baik : 5 (kualitas sangat baik, mudah dipahami, sangat sesuai dengan konteks penjelasan)

Baik : 4 (kualitas baik, mudah dipahami, sesuai dengan konteks penjelasan)

Cukup Baik : 3 (kualitas baik, mudah dipahami, perlu disempurnakan konteks penjelasan)

Kurang Baik : 2 (kualitas baik, sulit dipahami, perlu disempurnakan konteks penjelasan)

Tidak Baik : 1 (kualitas tidak baik, sulit dipahami, perlu disempurnakan konteks penjelasan)

Hasil penilaian dari para validator ini selanjutnya ditindaklanjuti oleh peneliti sesuai dengan saran dan komentar dari validator. Tingkat reliabilitas data antara tiga orang validator dihitung menggunakan interobserver agreement dengan menggunakan analisis statistik percentage of agreement (Watkins, 2001).

Keterangan:

$$
R=\left(\frac{A}{A+D}\right) \times 100 \%
$$

$\mathrm{R}$ (Percentage of Agreement) = Reliabilitas instrumen $\mathrm{A}($ Agreement $) \quad=$ Frekuensi kecocokan antara penilai $\mathrm{D}($ Disagreement $)=$ Frekuensi ketidakcocokan antara penilai

Kriteria penentuan reliabilitas persen kecocokan menurut Watkins (2001) adalah sebagai berikut:

$\begin{array}{ll}\mathrm{R}<40 \% & =\text { Tidak Baik } \\ 40 \%<\mathrm{R}<60 \% & =\text { Cukup Baik } \\ 60 \%<\mathrm{R}<75 \% & =\text { Baik } \\ \mathrm{R}>75 \% & \text { Sangat Baik }\end{array}$

Sementara itu menurut Borich (1994), instrumen dikatakan reliabel bila reliabilitas $\geq 0,75$ atau $75 \%$.

\section{Validitas Butir Soal}

Validitas adalah suatu ukuran yang menunjukkan tingkat-tingkat kesahihan sesuatu instrumen. Suatu instrumen yang valid mempunyai validitas yang tinggi, sebaliknya instrumen yang kurang valid mempunyai validitas yang rendah (Arikunto, 2010).

Penilaian tes penguasaan konsep dan penilaian tes keterampilan berpikir kritis ini meliputi validasi isi, validasi bahasa, dan penulisan soal.

Kriteria penilaian validasi isi:

$5=$ Sangat Valid, jika semua kriteria terpenuhi.

$4=$ Valid, jika empat dari lima kriteria terpenuhi.

3 = Cukup Valid, jika tiga dari lima kriteria terpenuhi.

2 = Kurang Valid, jika dua dari lima kriteria terpenuhi.
1 = Tidak Valid, jika hanya satu dari lima kriteria terpenuhi.

Kriteria validasi bahasa dan penulisan soal:

5 = Sangat dapat dipahami maksudnya, jika semua kriteria terpenuhi.

4 = Dapat dipahami maksudnya, jika empat dari lima kriteria terpenuhi.

3 = Cukup dapat dipahami maksudnya, jika tiga dari lima kriteria terpenuhi.

2 = Kurang dapat dipahami maksudnya, jika dua dari lima kriteria terpenuhi.

1 = Tidak dapat dipahami maksudnya, jika hanya satu dari lima kriteria terpenuhi.

Kelayakan butir soal disimpulkan dengan kriteria:

Rata-rata $4-5=$ Tidak Revisi (Valid)

Rata-rata 3-3,9 = Revisi Kecil (Cukup Valid)

Rata-rata $1-2,9=$ Revisi Besar (Tidak Valid)

\section{Sensitivitas Butir Soal}

Penentuan sensitivitas butir tes pilihan ganda (tes penguasaan konsep) digunakan rumus: Gronlund (1985); Okonkwo \& Osuji (2006).

$$
\mathrm{S}=\frac{\mathrm{Ra}-\mathrm{Rb}}{\mathrm{T}}
$$

Keterangan:

$$
\begin{aligned}
& \mathrm{S}=\text { Indeks sensitivitas butir soal } \\
& \mathbf{R} \mathbf{a}=\text { Jumlah siswa yang menjawab dengan benar soal post test } \\
& \mathbf{R E}=\text { Jumlah siswa yang menjawab dengan benar soal pre test } \\
& \mathrm{T}=\text { Jumlah siswa yang mengikuti tes }
\end{aligned}
$$

Sementara sensitivitas butir tes esai (tes keterampilan berpikir kritis) digunakan rumus: (Gronlund, 1985)

Keterangan:

$$
\mathrm{S}=\frac{\sum_{1}^{n} \operatorname{Ses}-\sum_{1}^{n} \mathrm{Seb}}{\mathrm{N}\left(\mathrm{Skor}_{\max }-\mathrm{Skor}_{\min }\right)}
$$

$\mathrm{S}=$ Indeks sensitivitas butir soal

$\mathrm{N}=$ Banyaknya siswa yang mengikuti tes awal dan akhir

$\Sigma_{1}^{\pi}$ Ses $=$ Jumlah skor subyek setelah proses pembelajaran

$\Sigma_{i} S_{e b}=$ Jumlah skor subyek sebelum proses pembelajaran

Skor $_{\max }=$ Skor maksimal yang dicapai siswa

Skor $_{\min }=$ Skor minimal yang dicapai siswa

Kriteria indeks sensitivitas adalah sebagai berikut:

- Butir soal yang ideal menghasilkan nilai indeks 1,00.

- Butir soal yang efektif mempunyai indeks antara 0,00 sampai 1,00, semakin bernilai positif, semakin sensitif butir soal tersebut terhadap pembelajaran, dan

- Butir soal dengan nilai nol dan negatif tidak peka atau sensitif terhadap pembelajaran (Okonkwo \& Osuji, 2006).

\section{Analisis Keterbacaan Handout dan LKS}

Keterbacaan Handout dan LKS dianalisis secara statistik deskriptif berdasarkan penilaian dan koreksi siswa yang mengisi instrumen. Selanjutnya dihitung persentase hasil jawaban siswa dan divisualisasikan dalam bentuk diagram batang.

\section{Analisis Keterlaksanaan RPP}

Keterlaksanaan RPP dianalisis secara deskriptif kualitatif, yaitu dengan membandingkan rata-rata skala 
penilaian yang diberikan kedua pengamat dengan kriteria penilaian sebagai berikut: (Arikunto, 2010)

$1,00-1,49$ : Tidak baik

$1,50-2,49$ : Kurang Baik

2,50-3,49 : Cukup Baik

$3,50-4,49$ : Baik

$4,50-5,00:$ Sangat baik

Tingkat reliabilitas data antara dua orang pengamat dihitung menggunakan interobserver agreement (Watkins, 2001).

\section{Analisis Pengamatan Aktivitas Siswa}

Aktivitas siswa selama kegiatan pembelajaran dianalisis secara statistik deskriptif berdasarkan ratarata hasil pengamatan dari dua pengamat. Selanjutnya dihitung persentase hasil pengamatan aktivitas siswa tersebut dan divisualisasikan dalam bentuk diagram batang. Tingkat reliabilitas data antara dua orang pengamat dihitung menggunakan nilai kecocokan antarpengamat (Percentage of Agreement) menurut Emmer \& Millet (dalam Borich, 1994).

Keterangan:

$$
R=100\left(1-\frac{A-B}{A+D}\right) \times 100 \%
$$

$\mathrm{R}$ (Percentage of Agreement) $=$ Reliabilitas instrumen

$\mathrm{A}$ dan $\mathrm{B}=$ Frekuensi aktivitas siswa oleh pengamat 1 dan 2 (A nilai frekuensi yang lebih besar)

Kriteria penentuan reliabilitas persen kecocokan menurut Watkins (2001: 209) dan Borich (1994: 385).

\section{Analisis Respon Siswa}

Angket respon siswa dinilai berdasarkan skala Likert dalam Sukmadinata (2012); Sugiyono (2012):

1) Sangat Setuju (SS) diberi nilai : 4

2) Setuju (S) diberi nilai

3) Tidak Setuju (TS) diberi nilai 3

4) Sangat Tidak Setuju (STS) diberi nilai : 1

Data angket respon siswa dianalisis dengan rumus:

Jumlah siswa yangmenjawab item Jumlah responden

Kriteria persentase respon siswa adalah:

$0 \%-20 \% \quad$ : Kurang sekali

$21 \%-40 \%$ : Kurang

$41 \%-60 \%:$ Cukup

$61 \%-80 \%$ : Kuat

$81 \%-100 \%$ : Sangat kuat

\section{Analisis Penguasaan Konsep dan Keterampilan Berpikir Kritis}

Penguasaan konsep siswa dianalisis dengan menghitung persen ketuntasan penguasaan konsep secara individual dan klasikal: (Trianto, 2010).

Ketuntasan individu $=\frac{\text { Jumlah skordiperoleh siswa }}{\text { Jumlah skor maksimal }} \times 100 \%$

Jumlah skor maksimal $=$ jumlah item $\mathrm{x}$ skor maksimal tiap item.

\footnotetext{
Ketuntasan klasilal $=\frac{\text { Jumlah siswa yang tuntas }}{\text { Jumlah siswa selurulunya }} \times 100 \%$

Retuntasanindikator $=\frac{\text { Jumlah siswa yang tuntas indikator }}{\text { Jumlah siswa seluruhnya }} \times 100 \%$
}

Siswa dikatakan tuntas (kompeten) jika siswa secara individu memperoleh nilai $\geq 75$ (sesuai KKM) dan pembelajaran dikatakan tuntas secara klasikal jika terdapat $75 \%$ mencapai nilai $\geq 75$. Ketuntasan belajar setiap indikator yang telah ditetapkan dalam suatu kompetensi dasar berkisar antara $0-100 \%$. Kriteria ideal ketuntasan setiap indikator adalah 75\% (BSNP, 2006).

Peningkatan skor penguasaan konsep, keterampilan berpikir kritis siswa dan ketuntasan indikator dihitung dengan gain score (skor peningkatan) Hake (1999)

$$
<\mathrm{g}>=\left(\%<\mathrm{S}_{\mathrm{f}}>-\%<\mathrm{S}_{\mathrm{i}}>\right) /\left(100-\%<\mathrm{S}_{\mathrm{i}}>\right)
$$

Keterangan:

$<\mathrm{g}>=$ Gain score average (skor peningkatan ratarata)

$\left.<\mathrm{S}_{\mathrm{f}}\right\rangle=$ Rata-rata nilai final (post test)

$<\mathrm{S}_{\mathrm{i}}>=$ Rata-rata nilai initial (pre test)

Klasifikasi gain adalah sebagai berikut:

$$
\begin{array}{ll}
<\mathrm{g}>>0,7 & : \text { gain } \text { tinggi } \\
0,7><\mathrm{g}>>0,3 & : \text { gain sedang } \\
<\mathrm{g}><0,3 & : \text { gain } \text { rendah }
\end{array}
$$

\section{Analisis Kendala dan Hambatan}

Kendala atau hambatan yang terjadi selama proses pembelajaran yang dicatat oleh pengamat dianalisis secara deskriptif kualitatif, selanjutnya ditindaklanjuti dengan merevisi perangkat pembelajaran yang dikembangkan.

\section{HASIL DAN PEMBAHASAN}

\section{A. Hasil Penilaian Kualitas Perangkat Pembelajaran}

\section{Hasil Validasi Perangkat Pembelajaran}

Hasil validasi perangkat pembelajaran oleh para pakar adalah sebagai berikut:

Tabel 1. Hasil Validasi Perangkat Pembelajaran

\begin{tabular}{|c|c|c|c|}
\hline No & $\begin{array}{c}\text { Perangkat } \\
\text { Pembelajaran }\end{array}$ & $\begin{array}{c}\text { Rata-rata } \\
\text { Penilaian }\end{array}$ & Kategori \\
\hline 1. & RPP & 4,29 & Baik \\
\hline 2. & Handout & 4,57 & Sangat Baik \\
\hline 3. & LKS & 4,42 & Baik \\
\hline
\end{tabular}

\begin{tabular}{|c|c|c|c|}
\hline No & $\begin{array}{c}\text { Perangkat } \\
\text { Pembelajaran }\end{array}$ & Penilaian Kelayakan & $\begin{array}{c}\text { Kategori } \\
\text { Sensitivitas }\end{array}$ \\
\hline 4. & $\begin{array}{c}\text { Tes Penilaian } \\
\text { Penguasaan Konsep }\end{array}$ & 21 Butir soal yang valid & Sensitif \\
\hline 5. & $\begin{array}{c}\text { Tes Keterampilan } \\
\text { Berpikir Kritis }\end{array}$ & $\begin{array}{c}\text { 12 Butir soal yang valid } \\
\text { 1 Butir soal yang cukup } \\
\text { valid }\end{array}$ & Sensitif \\
\hline
\end{tabular}

Berdasarkan analisis data kriteria kelayakan RPP berbasis model learning cycle $5 E$, menunjukkan bahwa RPP sudah dapat digunakan langsung dengan mudah oleh orang lain untuk mengajarkan materi yang sama. Hal ini dapat ditinjau dari segi isi yang menunjukkan kegiatan guru dan kegiatan siswa dirumuskan secara jelas dan operasional, sehingga mudah dilaksanakan dalam proses pembelajaran di kelas dan orang lain mudah memahaminya. Untuk format RPP sudah 
menunjukkan adanya kejelasan pembagian materi dan sistem penomoran. ditinjau dari segi komponen bahasa, bahasa yang digunakan dalam RPP menunjukkan sifat komunikatif, struktur kalimat yang sederhana, serta adanya kejelasan petunjuk dan arahan. RPP sudah mencantumkan pengalokasian waktu untuk setiap kegiatan pembelajaran sehingga memudahkan bagi orang lain untuk mengontrol kegiatan selama pembelajaran. Berdasarkan diskusi hasil penelitian tentang validasi RPP dapat disimpulkan bahwa RPP yang dikembangkan layak untuk digunakan sebagai perangkat pembelajaran.

Berdasarkan hasil analisis data kriteria kelayakan handout, menunjukkan bahwa handout yang dikembangkan mempunyai kelebihan daripada bukubuku yang telah digunakan oleh siswa selama ini. Kelebihannya adalah handout yang dikembangkan peneliti penuh warna sehingga menarik, gambargambar yang digunakan mudah dipahami dan sangat menunjang pemahaman materi yang ada dalam handout, diawali dengan tampilan fenomena dalam kehidupan sehari-hari yang menarik keingintahuan siswa untuk mempelajari fenomena tersebut serta mendorong siswa untuk mencari informasi lebih lanjut, dan handout disusun sesuai dengan tingkat perkembangan siswa, sehingga dapat disimpulkan bahwa handout yang dikembangkan layak digunakan sebagai perangkat pembelajaran karena sudah memenuhi standar validitas.

Berdasarkan hasil analisis data kriteria kelayakan LKS, menunjukkan bahwa LKS yang dikembangkan mempunyai kelebihan daripada LKSLKS yang telah digunakan oleh siswa selama ini. Kelebihannya adalah LKS yang dikembangkan peneliti penuh warna sehingga menarik, gambar-gambar yang digunakan mudah dipahami dan sangat menunjang pemahaman materi yang ada dalam LKS, diawali dengan tampilan fenomena dan pertanyaan-pertanyaan dalam kehidupan sehari-hari yang menarik keingintahuan siswa untuk mempelajari dan mencari informasi lebih lanjut tentang fenomena tersebut serta melatihkan keterampilan berpikir kritis siswa, dan LKS disusun sesuai dengan tingkat perkembangan siswa, sehingga dapat disimpulkan bahwa LKS yang dikembangkan layak digunakan sebagai perangkat pembelajaran karena sudah memenuhi standar validitas.

Hasil analisis validasi perangkat tes penguasaan konsep menunjukkan bahwa penilaian kelayakan tes penguasaan konsep dari validator menghasilkan 21 butir soal yang valid, bahasanya dapat dipahami, dan mendapat kesimpulan tanpa revisi atau layak, sehingga dapat digunakan dalam uji coba pembelajaran di kelas. Hasil analisis sensitivitas butir soal tes penguasaan konsep menunjukkan bahwa setiap indeks sensitivitas butir soal bernilai positif, maka butir soal tersebut dapat dikatakan lebih sensitif dan mempunyai efek besar dalam pembelajaran (Okonkwo dan Osuji, 2006), sehingga dapat disimpulkan bahwa tes penguasaan konsep yang dikembangkan mempunyai 21 soal pilihan ganda yang valid dan sensitif terhadap pembelajaran dan layak digunakan sebagai perangkat pembelajaran karena sudah memenuhi standar validitas.

Hasil analisis validasi perangkat tes keterampilan berpikir kritis menunjukkan bahwa penilaian kelayakan tes keterampilan berpikir kritis dari validator terhadap aspek validitas isi, serta bahasa dan penulisan soal menghasilkan 12 butir soal valid dan bahasanya dapat dipahami. Hasil analisis sensitivitas butir soal tes keterampilan berpikir kritis menunjukkan bahwa setiap indeks sensitivitas butir soal bernilai positif. Indeks sensitivitas butir soal tes keterampilan berpikir kritis seluruhnya berkategori sensitif, sehingga butir-butir soal tersebut dapat digunakan untuk mengukur keterampilan berpikir siswa dan sesuai dengan indikator yang diukur.

\section{Hasil Penilaian Keterbacaan Perangkat Pembelajaran}

Keterbacaan merupakan tingkat pemahaman siswa terhadap susunan kalimat dalam Handout dan LKS.

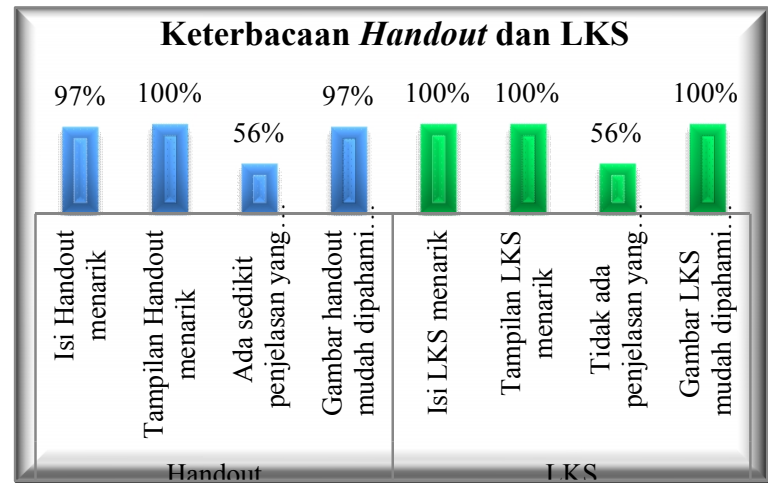

Gambar 2. Grafik Hasil Penilaian Keterbacaan Siswa terhadap Handout dan LKS

Berdasarkan data di atas dapat ditentukan bahwa perangkat handout dan LKS memiliki tingkat keterbacaan yang baik sehingga memenuhi syarat kualitas sebagai perangkat pembelajaran.

\section{B. Hasil Implementasi Perangkat Pembelajaran Berbasis Model Learning Cycle $5 E$ \\ 1. Keterlaksanaan RPP}

Tabel 2. Hasil Analisis Keterlaksanaan RPP Pertemuan Pertama, Kedua, dan Ketiga

\begin{tabular}{|c|c|c|c|c|c|c|c|c|c|c|c|}
\hline \multirow{2}{*}{ No } & \multirow{2}{*}{$\begin{array}{c}\text { Aspek yang } \\
\text { Diamati }\end{array}$} & \multicolumn{4}{|c|}{$\begin{array}{c}\text { Rata-rata } \\
\text { Keterlaksanaan }\end{array}$} & \multicolumn{4}{|c|}{$\begin{array}{l}\text { Rata-rata } \\
\text { Penilaian }\end{array}$} & \multirow{2}{*}{ Rata-rata } & \multirow{2}{*}{$\begin{array}{c}\text { Kate- } \\
\text { gori }\end{array}$} \\
\hline & & \begin{tabular}{l|}
$\mathrm{RPP}$ \\
$1.1 / \mathrm{I}$ \\
\end{tabular} & \begin{tabular}{|l|}
$\mathrm{RPP}$ \\
$1.2 / \mathrm{I}$
\end{tabular} & $\begin{array}{l}\text { RPP } \\
1 / I I \\
\end{array}$ & $\begin{array}{l}\mathrm{RPP} \\
1 / \mathrm{III} \\
\end{array}$ & $\begin{array}{l}\mathrm{RPP} \\
1.1 / \mathrm{I} \\
\end{array}$ & $\begin{array}{l}\mathrm{RPP} \\
1.2 / \mathrm{I} \\
\end{array}$ & \begin{tabular}{|l|}
$\mathrm{RPP}$ \\
$1 / \mathrm{II}$ \\
\end{tabular} & $\begin{array}{l}\mathrm{RPP} \\
1 / \mathrm{III}\end{array}$ & & \\
\hline \multicolumn{10}{|c|}{ A. Pendahuluan } & 4,61 & SB \\
\hline 1. & Engagement & $\mathrm{Ya}$ & $\mathrm{Ya}$ & $\mathrm{Ya}$ & $\mathrm{Ya}$ & 4,8 & 4,7 & 4,7 & 4,3 & 4,61 & SB \\
\hline \multicolumn{10}{|c|}{ B. Kegiatan Inti } & 4,30 & $\mathrm{~B}$ \\
\hline 2. & Exploration & $\mathrm{Ya}$ & $\mathrm{Ya}$ & Ya & $\mathrm{Ya}$ & 4,3 & 4,8 & 4,3 & 4,3 & 4,38 & B \\
\hline 3. & Explanation & $\overline{\mathrm{Ya}}$ & $\overline{\mathrm{Ya}}$ & $\mathrm{Ya}$ & $\mathrm{Ya}$ & 4,8 & 4,0 & 4,8 & 4,8 & 4,56 & SB \\
\hline
\end{tabular}

Implementasi Model 5E Learning Cycle untuk Meningkatkan Penguasaan Konsep dan Kemampuan Berpikir Kreatif Siswa SMA 


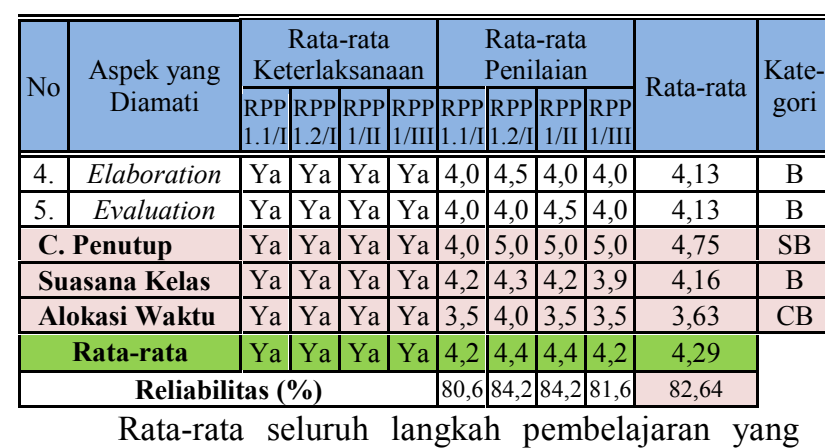

tertulis dalam RPP telah terlaksana. Rata-rata penilaian keterlaksanaan RPP adalah 4,29 dengan kategori baik yang menunjukkan bahwa RPP yang dikembangkan telah disusun dengan baik sehingga dapat dilaksanakan dengan baik dalam pembelajaran.

Rata-rata reliabilitas yang dihasilkan adalah $82,64 \%$, hal ini menunjukkan bahwa persentase kecocokan penilaian antara dua pengamat adalah sangat baik. Perhitungan relibilitas instrumen yang digunakan menunjukkan bahwa instrumen yang digunakan dapat dipercaya karena memiliki reliabilitas melebihi 75\% Borich (1994) dan Watkins (2001). Hasil tiga kali pelaksanaan RPP dapat disimpulkan bahwa keterlaksanaan RPP dikategorikan baik dengan reliabilitas kecocokan antar pengamat sangat baik.

\section{Aktivitas Siswa}

Pengamatan aktivitas siswa dilakukan oleh dua orang pengamat di SMKN 2 Tarakan.

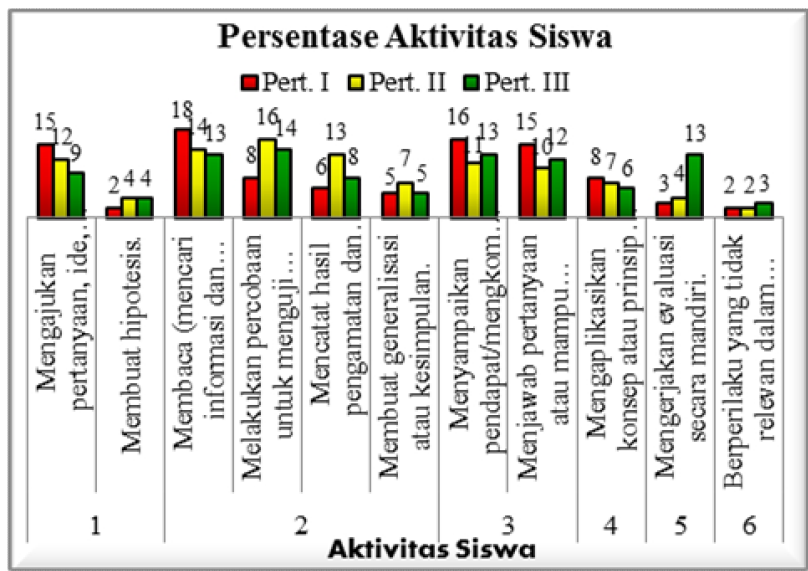

Gambar 3. Aktivitas Siswa dalam Pembelajaran Berbasis Model Learning Cycle $5 E$.

Aktivitas siswa yang menonjol adalah membaca (mencari informasi dan sebagainya) (15\%), melakukan percobaan untuk menguji hipotesis secara berkelompok (13\%), dan menyampaikan pendapat atau mengkomunikasikan informasi kepada kelas dan guru dalam diskusi kelas (13\%).

Secara umum aktivitas siswa selama proses pembelajaran menunjukkan frekuensi yang relatif stabil, hal ini disebabkan karena proses pembelajaran selalu mengikuti skenario yang terdapat pada rencana pelaksanaan pembelajaran (RPP) yang dikembangkan dan menggunakan perangkat pembelajaran termasuk media/alat yang sama selama kegiatan pembelajaran.

Hasil analisis menunjukkan bahwa model learning cycle $5 E$ dalam pembelajaran sesuai dengan pandangan kontruktivis yaitu membuat siswa belajar secara aktif (Hudojo, 2001 dalam Fajaroh, 2007), serta sesuai dengan teori belajar bermakna Ausubel, yang inti pokoknya sangat dekat dengan konstruktivisme, yang menekankan pentingnya siswa mengasosiasikan pengalaman, fenomena, dan fakta-fakta baru kedalam sistem pengertian yang telah siswa miliki serta menekankan pentingnya siswa aktif dalam proses belajar. Berdasarkan pandangan teori belajar konstruktivis menurut Slavin (2009) menganjurkan peranan yang lebih aktif dari siswa dalam pembelajaran mereka sendiri (student-centered instruction).

Belajar lebih dari sekedar mengingat, untuk benar-benar mengerti dan dapat menerapkan ilmu pengetahuan, siswa harus bekerja untuk memecahkan masalah, menemukan sesuatu bagi dirinya sendiri, dan harus membangun pengetahuan di dalam benak mereka agar konsep-konsep penting dan sangat berguna tertanam kuat dalam benak siswa (Piaget dalam Cook, 2005). Pengetahuan yang tertanam kuat dalam memori jangka panjang siswa tentunya akan dapat mempermudah siswa ingat dan pada akhirnya akan membantu meningkatkan penguasaan konsep serta kemampuannya dalam memecahkan masalah.

Perhitungan reliabilitas kecocokan antara dua orang pengamat menunjukkan bahwa instrumen pengamatan aktivitas siswa dalam pembelajaran learning cycle $5 E$ dapat dikatakan sangat baik, dengan reliabilitas rata-rata sebesar $89,67 \%$. Hal ini sesuai dengan ketentuan Watkins (2001) bahwa reliabilitas > 75\% dikatakan sangat baik, dan Borich (1994), bahwa jika nilai reliabilitas instrumen $\geq 75 \%$ dikategorikan instrumen yang baik.

\section{Respon Siswa}

Hasil penilaian respon siswa terhadap model pembelajaran berbasis learning cycle $5 E$ adalah seperti dalam Gambar 4.

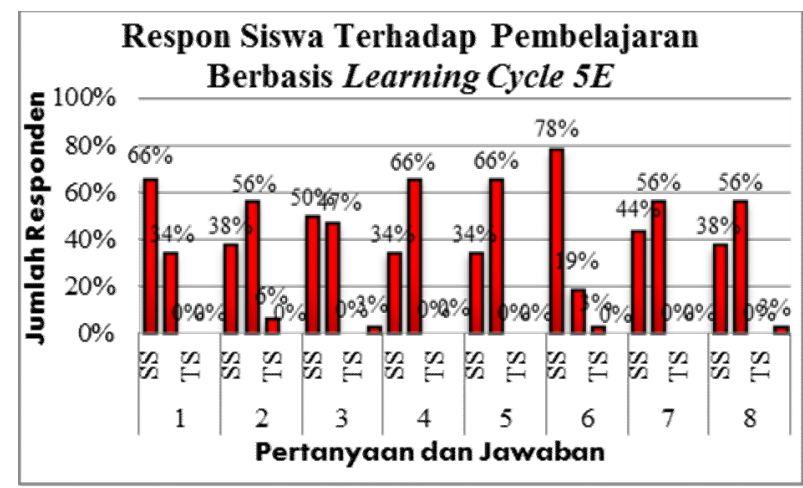

Gambar 4. Respon Siswa terhadap Pembelajaran Berbasis Model Learning Cycle $5 E$. 
Rata-rata penilaian respon siswa adalah 3,4 dengan kategori setuju, sehingga dapat disimpulkan bahwa siswa setuju model learning cycle $5 E$ dapat membuat siswa: (1) lebih senang belajar dengan langsung mengaplikasikan pelajaran atau materi yang didapat; (2) lebih berani untuk mengemukakan pendapat-pendapat yang ada dalam pikirannya, sehingga lebih cepat paham terhadap materi yang pelajarinya; (3) lebih aktif dalam kegiatan pembelajaran; (4) meningkatkan motivasi belajarnya; (5) lebih mudah mengerjakan soal-soal; (6) tertarik dan tidak bosan; (7) melatih keterampilan berpikir kritisnya; dan (8) meningkatkan penguasaan kosepnya.

Hasil ini sesuai dengan pendapat Hudojo (2001) dalam Fajaroh (2007) bahwa ditinjau dari dimensi siswa, penerapan model learning cycle $5 E$ memberi keuntungan dapat meningkatkan motivasi belajar karena siswa dilibatkan secara aktif dalam proses pembelajaran. Demikian juga menurut Fish (dalam Ergin, 2012) bahwa pendekatan model $5 E$ dapat menghasilkan: (1) prestasi yang lebih baik, (2) penyimpanan konsep dengan baik, (3) peningkatan sikap terhadap mata pelajaran, (4) peningkatan sikap terhadap pembelajaran, (5) peningkatan kemampuan penalaran, dan (6) keterampilan proses yang unggul.

\section{Penguasaan Konsep Siswa}

Penguasaan konsep merupakan salah satu indikator efektivitas perangkat pembelajaran yang dikembangkan. Berdasarkan data hasil penelitian dapat diketahui bahwa 29 siswa dari 32 siswa telah mendapatkan nilai post test yang mencapai bahkan melampaui KKM, dengan rata-rata skor 79,61, sehingga ketuntasan klasikalnya dapat mencapai $91 \%$. Tiga orang siswa yang belum tuntas selanjutnya diberikan remedial hingga tuntas. Ketidaktuntasan ini didukung dengan data aktivitas siswa yang tidak relevan selama pembelajaran berlangsung.

Setiap siswa dalam penelitian ini juga mengalami peningkatan penguasaan konsep dengan nilai rata-rata gain adalah tinggi yaitu 0,8 . Menurut Hake (1999) nilai gain > 0,7 diklasifikasikan sebagai gain tinggi.

Penguasaan konsep yang tinggi menunjukkan bahwa tahap-tahap dalam pembelajaran model learning cycle $5 E$ mampu membantu siswa dalam proses konstruksi konsep sehingga meningkatkan daya akomodasi konsepnya serta berpusat pada siswa. Keterlibatan siswa secara aktif dalam pembelajaran menyebabkan penyimpanan informasi ke memori jangka panjang (Slavin, 2009).

Sejalan dengan teori pemrosesan informasi, bahwa belajar bermakna merupakan suatu proses mengkaitkan informasi baru pada konsep-konsep relevan yang terdapat dalam struktur kognitif seseorang
(Ausubel: 1968). Reigeluth dan Stein (1983) mengatakan bahwa pengetahuan ditata di dalam struktur kognitif secara hirarkhis, sehingga pengetahuan yang lebih umum dan abstrak yang diperoleh lebih dulu dapat mempermudah perolehan pengetahuan baru yang lebih rinci.

Tingginya nilai gain menunjukkan pembelajaran learning cycle $5 E$ dapat meningkatkan penguasaan konsep siswa pada materi pokok laju reaksi. Senada dengan hasil penelitian Soeprodjo (2008) bahwa ada pengaruh positif penggunaan model learning cycle terhadap hasil belajar siswa pada pokok bahasan kelarutan dan hasil kali kelarutan; Qarareh (2012) dan Fish (1999) mengungkapkan efektivitas learning cycle $5 E$ pada hasil pendidikan seperti prestasi dan penyimpanan konsep dengan baik; Sihaloho dkk. (2013) yang menyatakan bahwa pembelajaran learning cycle $5 E$ lebih efektif dalam meningkatkan motivasi dan penguasaaan konsep siswa daripada pembelajaran konvensional; serta Bell (2012) bahwa learning cycle $5 E$ mendorong pembelajaran bermakna, hal ini tentu saja akan membuat penguasaan konsep siswa akan meningkat.

Tabel 3. Ketuntasan Indikator Tes Penguasaan Konsep dan Skor Peningkatan (Gain)

\begin{tabular}{|c|c|c|c|c|c|c|c|}
\hline No & Indikator & $\begin{array}{l}\text { Skor } \\
\text { Pre } \\
\text { Test } \\
(\%) \\
\end{array}$ & $\begin{array}{l}\text { Skor } \\
\text { Post } \\
\text { Test } \\
(\%) \\
\end{array}$ & $\begin{array}{c}\text { Ketuntasan } \\
\text { Indikator }\end{array}$ & \begin{tabular}{|c|}
$\begin{array}{c}\text { Ketun- } \\
\text { tasan } \\
\text { Keselu- } \\
\text { ruhan }\end{array}$ \\
\end{tabular} & $\begin{array}{c}\text { Skor } \\
\text { Pening- } \\
\text { katan } \\
\text { (Gain) } \\
\end{array}$ & $\begin{array}{c}\text { Kate- } \\
\text { gori }\end{array}$ \\
\hline & Produk & & & & & & \\
\hline 1. & 1 & 0 & 50 & Tdk Tuntas & \multirow{12}{*}{$100 \%$} & 0,5 & Sedang \\
\hline 2. & 2 & 3 & 75 & Tuntas & & 0,7 & Sedang \\
\hline 3. & 3 & 0 & 75 & Tuntas & & 0,8 & Tinggi \\
\hline 4. & 4 & 3 & 78 & Tuntas & & 0,8 & Tinggi \\
\hline \multirow[t]{2}{*}{5.} & 5 & 25 & 75 & Tuntas & & 0,7 & Sedang \\
\hline & Proses & & & & & & \\
\hline 6. & 6 & 25 & 75 & Tuntas & & 0,7 & Sedang \\
\hline 7. & 7 & 6 & 75 & Tuntas & & 0,7 & Sedang \\
\hline 8. & 8 & 13 & 78 & Tuntas & & 0,7 & Sedang \\
\hline 9. & 9 & 19 & 75 & Tuntas & & 0,7 & Sedang \\
\hline 10. & 10 & 16 & 81 & Tuntas & & 0,8 & Tinggi \\
\hline 11. & 11 & 25 & 78 & Tuntas & & 0,7 & Sedang \\
\hline \multicolumn{2}{|c|}{ Rata-rata } & 12,27 & 74,09 & & & 0,8 & 0,7 \\
\hline
\end{tabular}

Ketuntasan setiap indikator yang telah ditetapkan dalam suatu KD berkisar antara $0-100 \%$. Kriteria ideal ketuntasan untuk masing-masing indikator adalah 75\% (BSNP, 2006). 10 Dari 11 indikator pada KD menjelaskan faktor-faktor yang mempengaruhi laju reaksi telah dapat dicapai siswa $\geq$ $75 \%$, sehingga indikator produk dan proses dapat dikatakan $91 \%$ tuntas. Hampir setiap indikator mengalami peningkatan skor, dengan rata-rata gain adalah 0,7 yang kategorinya sedang. Tingginya nilai gain membuktikan bahwa model learning cycle $5 E$ dapat digunakan sebagai salah satu cara dalam mencapai ketuntasan indikator dalam KD menjelaskan faktor-faktor yang mempengaruhi laju reaksi. 


\section{Keterampilan Berpikir Kritis Siswa}

Keterampilan berpikir kritis siswa adalah keterampilan siswa dalam menyelesaikan suatu masalah yang tercermin melalui indikator (1) menjawab pertanyaan mengapa; (2) kemampuan memberikan alasan; (3) membuat generalisasi, kesimpulan dan hipotesis; (4) mengaplikasikan prinsip yang diterima; serta (5) merumuskan alternatif yang memungkinkan untuk memecahkan masalah.

Tabel 4. Skor Gain Keterampilan Berpikir Kritis Siswa

\begin{tabular}{|c|c|c|c|c|c|}
\hline \hline No & Siswa & $\begin{array}{c}\text { Skor } \\
\text { Pre Test (\%) }\end{array}$ & $\begin{array}{c}\text { Skor } \\
\text { Post Test (\%) }\end{array}$ & $\begin{array}{c}\text { Skor } \\
\text { Gain }\end{array}$ & Kategori \\
\hline \hline 1. & 01 & 19 & 91 & 0,9 & Tinggi \\
\hline 2. & 02 & 19 & 76 & 0,7 & Tinggi \\
\hline 3. & 03 & 10 & 75 & 0,7 & Tinggi \\
\hline 4. & 04 & 9 & 51 & 0,5 & Sedang \\
\hline 5. & 05 & 12 & 81 & 0,8 & Tinggi \\
\hline 6. & 06 & 14 & 94 & 0,9 & Tinggi \\
\hline 7. & 07 & 18 & 81 & 0,8 & Tinggi \\
\hline 8. & 08 & 4 & 77 & 0,8 & Tinggi \\
\hline 9. & 09 & 22 & 63 & 0,5 & Sedang \\
\hline 10. & 10 & 22 & 100 & 1,0 & Tinggi \\
\hline 11. & 11 & 15 & 78 & 0,7 & Tinggi \\
\hline 12. & 12 & 18 & 89 & 0,9 & Tinggi \\
\hline 13. & 13 & 19 & 85 & 0,8 & Tinggi \\
\hline 14. & 14 & 12 & 78 & 0,8 & Tinggi \\
\hline 15. & 15 & 13 & 87 & 0,9 & Tinggi \\
\hline 16. & 16 & 10 & 89 & 0,9 & Tinggi \\
\hline 17. & 17 & 20 & 85 & 0,8 & Tinggi \\
\hline 18. & 18 & 4 & 100 & 1,0 & Tinggi \\
\hline 19. & 19 & 6 & 86 & 0,9 & Tinggi \\
\hline 20. & 20 & 41 & 86 & 0,8 & Tinggi \\
\hline 21. & 21 & 15 & 88 & 0,9 & Tinggi \\
\hline 22. & 22 & 9 & 77 & 0,7 & Tinggi \\
\hline 23. & 23 & 14 & 67 & 0,6 & Sedang \\
\hline 24. & 24 & 12 & 83 & 0,8 & Tinggi \\
\hline 25. & 25 & 27 & 91 & 0,9 & Tinggi \\
\hline 26. & 26 & 8 & 83 & 0,8 & Tinggi \\
\hline 27. & 27 & 12 & 81 & 0,8 & Tinggi \\
\hline 28. & 28 & 9 & 80 & 0,8 & Tinggi \\
\hline 29. & 29 & 0 & 76 & 0,8 & Tinggi \\
\hline 30. & 30 & 16 & 77 & 0,7 & Tinggi \\
\hline 31. & 31 & 44 & 89 & 0,8 & Tinggi \\
\hline 32. & 32 & 20 & 94 & 0,9 & Tinggi \\
\hline \hline Rata-rata & $\mathbf{1 5 , 4 1}$ & $\mathbf{8 2 , 4 4}$ & $\mathbf{0 , 8}$ & Tinggi \\
\hline \hline & $T i n g$ & & & & \\
\hline
\end{tabular}

Tingginya nilai gain menunjukkan pembelajaran model learning cycle $5 E$ beserta perangkat pembelajaran yang dikembangkan ini dapat meningkatkan keterampilan berpikir kritis siswa. Hasil ini sejalan dengan penelitian Aydin dan Yilmas (2010); juga Fish (dalam Ergin, 2012) yang telah membuktikan adanya peningkatan kemampuan berpikir kritis dan kemampuan penalaran pada siswa yang mendapatkan pembelajaran dengan model learning cycle $5 E$ dibandingkan siswa yang mendapatkan pembelajaran dengan model konvensional.

Tabel 5. Persentase Ketuntasan Indikator Tes

Keterampilan Berpikir Kritis dan Skor Peningkatan

\begin{tabular}{|c|c|c|c|c|c|}
\hline \hline No. & Indikator & $\begin{array}{c}\text { Skor } \\
\text { Pre Test (\%) }\end{array}$ & $\begin{array}{c}\text { Skor } \\
\text { Post Test (\%) }\end{array}$ & $\begin{array}{c}\text { Skor } \\
\text { Gain }\end{array}$ & Kategori \\
\hline \hline 1. & 1 & 3 & 78 & 0,8 & Tinggi \\
\hline 2. & 2 & 0 & 81 & 0,8 & Tinggi \\
\hline 3. & 3 & 3 & 72 & 0,7 & Sedang \\
\hline
\end{tabular}

\begin{tabular}{|c|c|c|c|c|c|}
\cline { 2 - 4 } 4. & 4 & 0 & 81 & 0,8 & Tinggi \\
\hline 5. & 5 & 0 & 47 & 0,5 & Sedang \\
\hline \hline \multicolumn{2}{|c|}{ Rata-rata } & $\mathbf{1 , 2 0}$ & $\mathbf{7 1 , 8 0}$ & $\mathbf{0 , 7}$ & Sedang \\
\hline \hline
\end{tabular}

Tingginya persentase ketuntasan indikator berpikir kritis terutama pada kemampuan memberikan alasan dan mengaplikasikan prinsip yang diterima, dimungkinkan karena tahapan model pembelajaran learning cycle $5 E$ memberikan kesempatan yang lebih besar dalam melakukan tanya jawab, terutama pada tahap engagement, exploration, explanation, dan elaboration. Hasil ini menunjukkan bahwa pembelajaran learning cycle $5 E$ sesuai untuk mengajarkan indikator-indikator keterampilan berpikir kritis yang diteliti.

Adanya peningkatan skor pada kategori sedang, dimungkinkan karena adanya siswa yang tidak serius atau aktivitas siswa yang tidak relevan selama pembelajaran berlangsung, seperti percakapan yang tidak perlu, mengerjakan sesuatu yang tidak berkaitan dengan proses pembelajaran, atau mengganggu teman. Setelah implementasi dapat disimpulkan bahwa model learning cycle $5 E$ beserta perangkat pembelajaran yang dikembangkan dapat digunakan untuk meningkatkan keterampilan berpikir kritis siswa.

6. Kendala atau Hambatan selama Pembelajaran

Tabel 6. Kendala dan Hambatan dalam Pembelajaran Berbasis Model Learning Cycle $5 E$

\begin{tabular}{|c|l|l|}
\hline \hline No & \multicolumn{1}{|c|}{ Kendala atau Hambatan } & \multicolumn{1}{c|}{ Solusi } \\
\hline \hline 1. & $\begin{array}{l}\text { Jumlah siswa yang cukup besar dan } \\
\text { pengelolaan kelas kurang efektif } \\
\text { sehingga masih ada siswa yang } \\
\text { kurang terperhatikan. }\end{array}$ & $\begin{array}{l}\text { Guru hendaknya } \\
\text { melakukan } \\
\text { pengelolaan kelas } \\
\text { dengan lebih efektif. }\end{array}$ \\
\hline 2. & $\begin{array}{l}\text { Kurangnya alat-alat praktikum yang } \\
\text { dibutuhkan. }\end{array}$ & $\begin{array}{l}\text { Membentuk kelompok } \\
\text { dengan jumlah siswa } \\
\text { yang lebih banyak. }\end{array}$ \\
\hline & $\begin{array}{l}\text { Kendala dalam waktu pembelajaran, } \\
\text { dengan cukup banyaknya siswa } \\
\text { sehingga waktu yang diperlukan } \\
\text { menjadi lebih banyak untuk membagi } \\
\text { alat, bahan praktikum, handout, } \text { LKS, } \\
\text { soal tes, serta angket. }\end{array}$ & $\begin{array}{l}\text { Mengalokasikan } \\
\text { waktu secara lebih } \\
\text { tepat dan membagikan } \\
\text { handout, LKS, serta } \\
\text { angket sebelum } \\
\text { pembelajaran. }\end{array}$ \\
\hline
\end{tabular}

Kendala ini sejalan dengan pendapat Soebagio (2000) dalam Fajaroh (2007) yang menyatakan bahwa dalam model pembelajaran learning cycle 5E: (1) Efektifitas pembelajaran rendah jika guru kurang menguasai materi dan langkah-langkah pembelajaran; (2) Menuntut kesungguhan dan kreativitas guru dalam merancang dan melaksanakan proses pembelajaran; (3) Memerlukan pengelolaan kelas yang lebih terencana dan terorganisasi; serta (4) Memerlukan waktu dan tenaga yang lebih banyak dalam menyusun rencana dan melaksanakan pembelajaran. Hal ini seharusnya diantisipasi oleh guru agar pembelajaran menjadi lebih efektif. 


\section{PENUTUP}

\section{Simpulan}

Berdasarkan temuan hasil penelitian dapat disimpulkan bahwa perangkat pembelajaran berbasis model learning cycle $5 E$ pada materi pokok laju reaksi yang dihasilkan layak digunakan dalam pembelajaran kimia di SMK.

\section{Saran}

Perangkat pembelajaran kimia berbasis model learning cycle $5 E$ pada materi laju reaksi yang dihasilkan dapat digunakan sebagai acuan bagi guru kimia untuk mengembangkan perangkat pembelajaran sejenis pada materi pokok yang lain. Guru hendaknya menguasai materi, menguasai langkah-langkah pembelajaran, mempersiapkan pembelajaran, serta dapat mengelola kelas dengan baik agar pembelajaran model learning cycle $5 E$ lebih efektif untuk meningkatkan keterampilan berpikir kritis dan hasil belajar siswa.

\section{DAFTAR PUSTAKA}

Arikunto, S. 2010. Prosedur Penelitian. Suatu Pendekatan Praktik. Edisi Revisi. Jakarta: Rineka Cipta.

Ausubel, D. P. 1968. Educational Psychology: A Cognitive View. New York: Holt, Rinehart \& Winston.

Aydin, N. \& Yilmas, A. 2010. "The Effect of Constructivist Approach in Chemistry Education on Students' Higher Order Cognitive Skills" Hacettepe Üniversitesi Journal of Education. 39. 57 - 68.

Balitbang Kemendikbud. 2011. Survei Internasional TIMSS.http://litbang.kemdikbud.go.id/detail.php?id=21 4 Diakses pada tanggal 26 Nopember 2012.

Bell, C. V. \& Odom, A. L. 2012. "Reflections on Discourse Practices During Professional Development on the Learning Cycle". Journal Science Teacher Education. 23 (6).

Borich, G. D. 1994. Observation Skill for Effective Teaching. New York: Macmillan Publishing Company.

BSNP. 2006. Panduan Penyusunan Kurikulum Tingkat Satuan Pendidikan Jenjang Pendidikan Dasar dan Menengah. Jakarta: BSNP.

Cook, J. L. \& Cook, G. 2005. Child Development: Principles \& Perspectives. Boston: Allyn \& Bacon.

Ergin, I, Kanli, U \& Unsal, Y. 2008. "An Example for the Effect of the 5E Model on the Academic Success and Attitude Levels of Students': Inclined Projectile Motion." Journal of Turkish Science Education, 5 (3) $47-59$.

Fajaroh, F. \& Dasna, I. W. 2007. Pembelajaran dengan Model Siklus Belajar (Learning Cycle).

http://lubisgrafura.wordpress.com/2007/09/20/pembelajarandengan-model-siklus-belajar-learning-cycle/. Diakses pada tanggal 31 Desember 2012.

Fish, L. 1999. "Why Use the 5E Model for Teaching Science?". In Ergin, I. 2012. "Constructivist Approach Based 5E Model and Usability Instructional Physics." Latin American Journal of Physics Education, 6 (1) 14 -20 .
Fraenkel, J. R., Wallen, N. E., \& Hyun, H. H. 2012. How to Design and Evaluate Research in Education. New York: McGraw-Hill Companies, Inc.

Gronlund, N. E. 1985. Constructing Achievement Test. $5^{\text {th }}$ Edition. New York: Prentice Hall Inc.

Hake, R. R. 1999. Analyzing Change/Gain Scores. USA: Department of Physics, Indiana University.

Hokkanen, S. L. 2011. "Improving Student in Science Through the Implementation of the 5E Learning Cycle in the Middle Grades of an Urban School". Thesis Masters of Science in Science Education, Montana State University.

Hudha, A.M., Husamah, \& Hadi, S. 2011. "Pendampingan Pengembangan Perangkat Pembelajaran Laboratorium untuk Menunjang Pelaksanaan KTSP Bagi Guru IPA Biologi SMP Muhammadiyah 1 Malang." Jurnal Dedikasi, 8 p. 43 - 51 .

Ibrahim, M. 2002. Modul Pelatihan Terintegrasi Berbasis Kompetensi Guru Mata Pelajaran Biologi: Pengembangan Perangkat Pembelajaran. Jakarta: Direktorat Jenderal Pendidikan Dasar dan Menengah, Depdiknas.

Institute of Museum and Library Services. 2009. Museums, Libraries and $21^{\text {st }}$ Century Skills. Washington: IMLS Office of Strategic Partnerships.

Okonkwo \& Osuji. 2006. EDU 403: Measurement and Evaluation. Victoria Island: National Open University of Nigeria.

Partnership for 21st Century Skills. 2008. 21st Century Skills, Education \& Competitiveness: A Resource and Policy Guide. Partnership for 21st Century Skills.

Permendikbud. 2013. Peraturan Menteri Pendidikan dan Kebudayaan Republik Indonesia Nomor 70 Tahun 2013 tentang Kerangka Dasar dan Struktur Kurikulum Sekolah Menengah Kejuruan/Madrasah Aliyah Kejuruan. Jakarta: Departemen Pendidikan dan Kebudayaan Republik Indonesia.

Permendiknas. 2006. Peraturan Menteri Pendidikan Nasional Republik Indonesia Nomor 23 Tahun 2006 tentang Standar Kompetensi Lulusan untuk Satuan Pendidikan Dasar dan Menengah. Jakarta: Depdiknas.

Qarareh, A. O. 2012. "The Effect of Using the Learning Cycle Method in Teaching Science on the Educational Achievement of the Sixth Graders." International Journal Education Science. 4 (2) 123 - 132.

Reigeluth, C.M., \& Stein, F. 1983. "The Elaboration Theory of Instruction". In Reigeluth, C.M. Instructional Design Theories and Models: An Overview of the Current Status. Hillsdale, New York: Lawrence Erlbaum Associates.

Sihaloho, L. M., Rudibyani, R. B., \& Efkar, T. 2013. "Peningkatan Motivasi dan Penguasaan Konsep Melalui Model Learning Cycle 5E”. Jurnal Pendidikan Kimia. 1 (7).

Slavin, R. E. 2009. Educational Psychology: Theory and Practice. $9^{\text {th }}$ Edition. Boston: Allyn \& Bacon. 
Soeprodjo, P. S., \& Sariana, E. Y. 2008. "Pengaruh Model Learning Cycle terhadap Hasil Belajar Materi Kelarutan dan Hasil Kali Kelarutan”. Jurnal Inovasi Pendidikan Kimia. 2 (1) $224-229$.

Sugiyono. 2012. Metode Penelitian Kuantitatif Kualitatif dan $R \& D$. Bandung: Alfabeta.

Sukmadinata, N. S. 2012. Metode Penelitian Pendidikan. Bandung: Rosda Karya.

Thiagarajan, S., Semmel, D. S., \& Semmel, M. I. 1974. Instructional Development for Training Teachers of Exceptional Children: A Sourcebook. Bloomington: Indiana University.

Trianto. 2010. Mendesain Model Pembelajaran InovatifProgresif: Konsep, Landasan, dan Implementasinya pada Kurikulum Tingkat Satuan Pendidikan (KTSP). Jakarta: Kencana Prenada Media Group.

Turk, F. \& Calik, M. 2008. "Using Different Conceptual Change Methods Embedded Within 5E Model: A Sample Teaching of Endothermic - Exothermic Reactions." Asia-Pacific Forum on Science Learning and Teaching, 9 (1).

Wagner, Tony. 2008. "Expecting Excellence: Rigor Redefined". Educational Leadership, 66 (2) 20 - 25.

Watkins, M. W. \& Pacheco, M. 2001. "Interobserver Agreement in Behavioral Research: Importance and Calculation." Journal of Behavioral Education, 10 (4).

Yulianti. 2010. "Pengembangan Perangkat Pembelajaran Peluang Berbasis Reciprocal Teaching untuk Melatih Kemampuan Berpikir Kritis Siswa Kelas XI SMK Negeri 3 Lubuklinggau." Jurnal Pendidikan Matematika, 4 (1). 